\title{
Highlight report: Translocation of nanoparticles through barriers
}

\author{
Christoph van Thriel ${ }^{1}$
}

Published online: 23 November 2015

(C) Springer-Verlag Berlin Heidelberg 2015

Recently, Hedwig Braakhuis from Maastricht University and other Dutch colleagues have published a comprehensive review about in vitro systems to study translocation of nanoparticles through barriers (Braakhuis et al. 2015). Numerous in vivo studies have shown that nanoparticles can cross the barrier of the lung, gut, skin and placenta (Balasubramanian et al. 2010; Braakhuis et al. 2015; Creutzenberg et al. 2012; Elder et al. 2006; Semmler et al. 2004) and translocate directly via axons of the olfactory nerve into the CNS (Oberdorster et al. 2004). The degree to which these barriers can be passed depends on the physicochemical properties of the particles and varies widely between different particle types. Therefore, it would represent a large progress if this capacity could be predicted in vitro. In their comprehensive review, Braakhuis and colleagues critically discuss the large number of in vitro systems of barriers particularly of lung, gut, skin and placenta. The authors conclude that although these systems allow identification of qualitative differences between particles they have not yet been sufficiently calibrated with respect to the in vivo situation. The currently available in vitro systems of barriers do not yet allow quantitative predictions of real organisms (Braakhuis et al. 2015).

Currently, nanotoxicology represents one of the most intensively studied fields of toxicology (Hammad et al. 2014; Marchan 2012; Stewart and Marchan 2012). A particular focus is to gain a deeper understanding of the influence of physiochemical properties (Austin et al. 2014;

Christoph van Thriel

thriel@ifado.de

Leibniz Research Centre for Working Environment and Human Factors, TU Dortmund, IfADo - Ardeystr. 67, 44139 Dortmund, Germany
Horie et al. 2013; Xiong et al. 2013), improve in vitro systems (Park et al. 2013, 2014; Bondarenko et al. 2013; Schluesener and Schluesener 2013; Hoelting et al. 2013) and predict genotoxic properties (Kumar and Dhawan 2013; Mohiuddin et al. 2014). In principle, in vitro systems of barriers (Braakhuis et al. 2015) could be integrated into in vitro systems aimed at predicting organ toxicity, such as liver (Godoy et al. 2013, 2015; Benet et al. 2014; Grinberg et al. 2014), kidney (Sanchez-Niño et al. 2014; Fujiki et al. 2014; Xu et al. 2013) and neuronal tissues (Waldmann et al. 2014; Krug et al. 2013; Frimat et al. 2010). On the other hand, it has been argued that due to limitations of in vitro systems further progress in nanotoxicology requires particularly adequate in vivo studies, for example to assess the long-term distribution and toxicity under exposure conditions relevant to humans (Gebel et al. 2014).

Considering the complexity of this field, the systematic review of Braakhuis et al. (2015) is extremely helpful for everyone who is interested in learning more about possibilities and limitations of in vitro systems to simulate nanoparticle translocation across the barriers of the human body.

\section{References}

Austin LA, Mackey MA, Dreaden EC, El-Sayed MA (2014) The optical, photothermal, and facile surface chemical properties of gold and silver nanoparticles in biodiagnostics, therapy, and drug delivery. Arch Toxicol 88(7):1391-1417. doi:10.1007/ s00204-014-1245-3

Balasubramanian SK, Jittiwat J, Manikandan J, Ong CN, Yu LE, Ong WY (2010) Biodistribution of gold nanoparticles and gene expression changes in the liver and spleen after intravenous administration in rats. Biomaterials 31(8):2034-2042. doi:10.1016/j.biomaterials.2009.11.079

Benet M, Moya M, Donato MT, Lahoz A, Hervás D, Guzmán C, Gómez-Lechón MJ, Castell JV, Jover R (2014) A simple 
transcriptomic signature able to predict drug-induced hepatic steatosis. Arch Toxicol 88(4):967-982. doi:10.1007/ s00204-014-1197-7

Bondarenko O, Juganson K, Ivask A, Kasemets K, Mortimer M, Kahru A (2013) Toxicity of Ag, $\mathrm{CuO}$ and $\mathrm{ZnO}$ nanoparticles to selected environmentally relevant test organisms and mammalian cells in vitro: a critical review. Arch Toxicol 87(7):1181-1200. doi:10.1007/s00204-013-1079-4

Braakhuis HM, Kloet SK, Kezic S, Kuper F, Park MV, Bellmann S, van der Zande M, Le Gac S, Krystek P, Peters RJ, Rietjens IM, Bouwmeester H (2015) Progress and future of in vitro models to study translocation of nanoparticles. Arch Toxicol 89(9):14691495. doi:10.1007/s00204-015-1518-5

Creutzenberg O, Bellmann B, Korolewitz R, Koch W, Mangelsdorf I, Tillmann T, Schaudien D (2012) Change in agglomeration status and toxicokinetic fate of various nanoparticles in vivo following lung exposure in rats. Inhal Toxicol 24(12):821-830. doi:10.310 9/08958378.2012.721097

Elder A, Gelein R, Silva V, Feikert T, Opanashuk L, Carter J, Potter R, Maynard A, Ito Y, Finkelstein J, Oberdörster G (2006) Translocation of inhaled ultrafine manganese oxide particles to the central nervous system. Environ Health Perspect 114(8):1172-1178. Erratum in: Environ Health Perspect 2006; 114(8):1178

Frimat JP, Sisnaiske J, Subbiah S, Menne H, Godoy P, Lampen P, Leist M, Franzke J, Hengstler JG, van Thriel C, West J (2010) The network formation assay: a spatially standardized neurite outgrowth analytical display for neurotoxicity screening. Lab Chip 10(6):701-709. doi:10.1039/b922193j

Fujiki K, Inamura H, Matsuoka M (2014) PI3K signaling mediates diverse regulation of ATF4 expression for the survival of HK-2 cells exposed to cadmium. Arch Toxicol 88(2):403-414. doi:10.1007/s00204-013-1129-y

Gebel T, Foth H, Damm G, Freyberger A, Kramer PJ, Lilienblum W, Röhl C, Schupp T, Weiss C, Wollin KM, Hengstler JG (2014) Manufactured nanomaterials: categorization and approaches to hazard assessment. Arch Toxicol 88(12):2191-2211. doi:10.1007/s00204-014-1383-7

Godoy P, Hewitt NJ, Albrecht U et al (2013) Recent advances in 2D and $3 \mathrm{D}$ in vitro systems using primary hepatocytes, alternative hepatocyte sources and non-parenchymal liver cells and their use in investigating mechanisms of hepatotoxicity, cell signaling and ADME. Arch Toxicol 87(8):1315-1530. doi:10.1007/ s00204-013-1078-5

Godoy P, Schmidt-Heck W, Natarajan K et al (2015) Gene networks and transcription factor motifs defining the differentiation of stem cells into hepatocyte-like cells. J Hepatol 63(4):934-942. doi:10.1016/j.jhep.2015.05.013

Grinberg M, Stöber RM, Edlund K et al (2014) Toxicogenomics directory of chemically exposed human hepatocytes. Arch Toxicol 88(12):2261-2287. doi:10.1007/s00204-014-1400-x

Hammad S, Abdou AM, Omar MA (2014) Gebel-criteria for risk assessment in nanotoxicology. EXCLI J 13:1196-1197

Hoelting L, Scheinhardt B, Bondarenko O, Schildknecht S, Kapitza M, Tanavde V, Tan B, Lee QY, Mecking S, Leist M, Kadereit $S$ (2013) A 3-dimensional human embryonic stem cell (hESC)-derived model to detect developmental neurotoxicity of nanoparticles. Arch Toxicol 87(4):721-733. doi:10.1007/ s00204-012-0984-2

Horie M, Kato H, Iwahashi H (2013) Cellular effects of manufactured nanoparticles: effect of adsorption ability of nanoparticles. Arch Toxicol 87(5):771-781. doi:10.1007/s00204-013-1033-5

Krug AK, Kolde R, Gaspar JA et al (2013) Human embryonic stem cell-derived test systems for developmental neurotoxicity: a transcriptomics approach. Arch Toxicol 87(1):123-143. doi:10.1007/ s00204-012-0967-3

Kumar A, Dhawan A (2013) Genotoxic and carcinogenic potential of engineered nanoparticles: an update. Arch Toxicol 87(11):18831900. doi:10.1007/s00204-013-1128-z

Marchan R (2012) A special issue on nanotoxicology. EXCLI J 11:176-177

Mohiuddin Keka IS, Evans TJ, Hirota K, Shimizu H, Kono K, Takeda S, Hirano S (2014) A novel genotoxicity assay of carbon nanotubes using functional macrophage receptor with collagenous structure (MARCO)-expressing chicken B lymphocytes. Arch Toxicol 88(1):145-160. doi:10.1007/s00204-013-1084-7

Oberdorster G, Sharp Z, Atudorei V, Elder A, Gelein R, Kreyling W, Cox C (2004) Translocation of inhaled ultrafine particles to the brain. Inhal Toxicol 16(6-7):437-445

Park EJ, Shim HW, Lee GH, Kim JH, Kim DW (2013) Comparison of toxicity between the different-type $\mathrm{TiO}_{2}$ nanowires in vivo and in vitro. Arch Toxicol 87(7):1219-1230. doi:10.1007/ s00204-013-1019-3

Park EJ, Umh HN, Choi DH, Cho MH, Choi W, Kim SW, Kim Y, Kim JH (2014) Magnetite- and maghemite-induced different toxicity in murine alveolar macrophage cells. Arch Toxicol 88(8):16071618. doi:10.1007/s00204-014-1210-1

Sanchez-Niño MD, Poveda J, Sanz AB, Carrasco S, Ruiz-Ortega M, Selgas R, Egido J, Ortiz A (2014) 3,4-DGE is cytotoxic and decreases HSP27/HSPB1 in podocytes. Arch Toxicol 88(3):597608. doi:10.1007/s00204-013-1181-7

Schluesener JK, Schluesener HJ (2013) Nanosilver: application and novel aspects of toxicology. Arch Toxicol 87(4):569-576. doi:10.1007/s00204-012-1007-z Epub 2013 Jan 24

Semmler M, Seitz J, Erbe F, Mayer P, Heyder J, Oberdörster G, Kreyling WG (2004) Long-term clearance kinetics of inhaled ultrafine insoluble iridium particles from the rat lung, including transient translocation into secondary organs. Inhal Toxicol 16(6-7):453-459

Stewart JD, Marchan R (2012) Current developments in toxicology. EXCLI J 11:692-702

Waldmann T, Rempel E, Balmer NV, König A, Kolde R, Gaspar JA, Henry M, Hescheler J, Sachinidis A, Rahnenführer J, Hengstler JG, Leist M (2014) Design principles of concentration-dependent transcriptome deviations in drug-exposed differentiating stem cells. Chem Res Toxicol 27(3):408-420. doi:10.1021/tx400402j

Xiong S, George S, Ji Z, Lin S, Yu H, Damoiseaux R, France B, Ng KW, Loo SC (2013) Size of $\mathrm{TiO}(2)$ nanoparticles influences their phototoxicity: an in vitro investigation. Arch Toxicol 87(1):99109. doi:10.1007/s00204-012-0912-5

Xu J, Li Z, Xu P, Xiao L, Yang Z (2013) Nanosized copper oxide induces apoptosis through oxidative stress in podocytes. Arch Toxicol 87(6):1067-1073. doi:10.1007/s00204-012-0925-0 